\title{
Sunflower cake with or without enzymatic complex for broiler chickens feeding
}

\author{
Eveline Berwanger ${ }^{1}$, Ricardo Vianna Nunes ${ }^{2}$, Tiago Junior Pasquetti ${ }^{3}$, Alice Eiko Murakami ${ }^{4}$, \\ Taciana Maria Moraes de Oliveira, ${ }^{4, *}$, Douglas Fernando Bayerle ${ }^{2}$, and Rafael Frank ${ }^{2}$
}

\footnotetext{
* Corresponding Author: Taciana Maria Moraes de Oliveira

Tel: +55-44-9903-5667,

E-mail: tacideoliveira@hotmail.com
}

${ }^{1}$ Animal Science Department, Federal University of South Rio Grande, Porto Alegre, RS 91540-000, Brazi

${ }^{2}$ Animal Science Department, State University of West

Paraná, Marechal Cândido Rondon, PR 85960-000, Brazil

${ }^{3}$ Animal Science Department, State University of South

Mato Grosso, Aquidauana, MS 79200-000, Brazil

${ }^{4}$ Animal Science Department, State University of

Maringá, Maringá, PR 87020-900, Brazil

Submitted Aug 1, 2015; Revised Nov 15, 2015; Accepted Mar 3, 2016
Objective: This study was to evaluate the sunflower cake and enzymatic complex fed to broilers from 22 to $42 \mathrm{~d}$ of age.

Methods: In a completely randomized design, a total of 850 birds were allotted in a $2 \times 5$ factorial scheme (with and without enzymatic complex) and five inclusion levels ( $0 \%, 5 \%$, $10 \%, 15 \%, 20 \%)$ of sunflower cake. There were 5 replications and 17 birds in each experimental unit. Data from performance, carcass yield and intestinal morphology were evaluated.

Results: Feed intake, weight gain, final weight and feed:gain ratio linearly worsened as sunflower cake increased. For weight gain, final weight and feed:gain ratio, the birds whose diets contained levels of $15 \%$ and $20 \%$ of sunflower cake showed worse values $(p<0.05)$ than the birds fed the control diet. When fed the enzymatic complex, birds improved $(\mathrm{p}<0.05)$ crypt depth and villus:crypt ratio in the jejunum. As inclusion levels of sunflower cake increased, villus depth and villus:crypt ratio in duodenum, jejunum and ileum linearly reduced and the crypt depth linearly increased. Carcass yield linearly reduced as sunflower cake increased. Conclusion: Based on performance, sunflower cake can be used up to $10 \%$ in broilers feeding from 21 to 42 days of age.

Keywords: Broilers; Sunflower Cake; Enzymes; Carcass Yield; Intestinal Morphometry; Performance

\section{INTRODUCTION}

The cost of feed accounts for most of the costs associated with animal production. This encourages the search for new ingredients that can reduce costs by effectively replacing corn or soybean meal, which represent the most common ingredients used in feed formulations [1]. In this regard, byproducts derived from the industrial processing of agricultural products have attracted the attention of researchers [2].

Sunflower cultivation has expanded significantly in Brazil and is considered one of the largest agricultural bases of the national program of renewable fuels [3] and is among the most common edible vegetable oil crop in the world.

The extraction of sunflower oil can be performed by two methods: The first and most efficient uses a chemical solvent (hexane) at high temperatures to obtain sunflower meal as a byproduct. The second method is characterized by cold-pressing sunflower seeds to obtain the crude oil, resulting in a byproduct known as sunflower cake (SC). This byproduct contains more ether extract (averaging 18\%) than sunflower meal, due to lower efficiency of the oil extraction method compared to the first type described [4].

The SC can be a good source of energy for broiler chickens and, as reported by Geron [5], its use in feed formulation for animals can reduce production costs and contribute to sustainable 
animal production by reducing environment contamination and improving the conservation of natural resources.

However, chemical composition of the SC can shows variation due to the genetics of the cultivar and due to processing of the seeds [6], which makes it essential to determine the nutritional values of SC before proceeding to include it in feed formulations.

Additionally, some factors can limit the feeding of SC to non-ruminants, such as its high concentration of non-starch polysaccharides, especially cellulose and lignin, which cannot be degraded by endogenous enzymes. The cellulolytic complex of the sunflower plant, therefore, acts as a barrier to birds' digestive systems, impairing enzyme action and increasing the endogenous nutrient loss, thus reducing the availability of energy from birds' diets [7]. To increase the efficiency of nutrient utilization from alternative foods it's commonly proposes the addition of exogenous enzymes. This study evaluates the performance traits, carcass yield and prime cuts, and the intestinal morphology of broiler chickens, from 22 to $42 \mathrm{~d}$ of age feeding diets with increasing levels of SC, with or without enzymatic complex supplementation.

\section{MATERIAL AND METHODS}

The experiment was conducted at the Poultry Section of State University of West Paraná (Unioeste), at the Campus of Marechal Cândido Rondon, PR, Brazil, and the experimental protocol $\left(\mathrm{n}^{\circ}\right.$ 04411/2011) was approved by Animal Care and Use Committee (Comitê de Ética na Experimentação Animal e Aulas Práticas - CEEAAP/UNIOESTE). The SC was acquired from a sunflower oil production facility in Toledo, PR. A prior digestibility assay determined the chemical and energetic composition and the digestible amino acids used to formulate the experimental diets [8].

Birds were acquired from a commercial Cobb Slow line breeder's incubatory and vaccinated for Marek's disease, Gumboro, fowlpox and infectious bronchitis. From 1 to $21 \mathrm{~d}$ of age, birds were created in a conventional barn with new wood shavings in which all birds received the same diet (pre-starter and initial) and water ad libitum. Heat and light was provided for the birds using infrared lamps of 250 watts and a $24 \mathrm{~h}$ lighting program. The maximum temperature and relative humidity were $29.33^{\circ} \mathrm{C}$ and $82.84 \%$, respectively, and the minimal temperature and relative humidity were $23.92^{\circ} \mathrm{C}$ and $73.50 \%$, respectively.

At $21 \mathrm{~d}$ of age birds were weighed individually and separated by weight. After weighing, 850 male broilers, averaging $740.27 \pm$ $3.77 \mathrm{~g}$, were distributed in a completely randomized design using a $2 \times 5$ factorial scheme that combined two treatments i) with and ii) without enzyme complex supplementation (pectinase, 4,000 U/g; protease, $700 \mathrm{U} / \mathrm{g}$; phytase, $300 \mathrm{U} / \mathrm{g}$; betaglucanase, $200 \mathrm{U} / g$; xilanase, $100 \mathrm{U} / \mathrm{g}$; celulase, $40 \mathrm{U} / \mathrm{g}$; and amilase, 30 $\mathrm{U} / \mathrm{g})$ and five levels of SC (0\%, 5\%, $10 \%, 15 \%$, and $20 \%)$ with five replications and 50 experimental units in total.
Diets and water were provided ad libitum for birds during the entire experimental period. Nutritional values of SC were used as proposed by Berwanger et al [8]. The diets were isonutritive, based on corn and soybean meal and formulated according to the requirements proposed by Rostagno et al [9] for birds from 21 to $35 \mathrm{~d}$ of age and from 36 to $42 \mathrm{~d}$ of age (Table 1). The enzymatic complex replaced the inert and a total of 0 was added to the birds' diets.

The birds' weight and feed intake (FI) were recorded weekly. Mortality was recorded to correct the FI and feed: gain (F:G) ratio [10], then weight gain (WG), FI, and F:G ratio were calculated. On $\mathrm{d} 42$, two birds (ranging $\pm 5 \%$ of the average weight of the experimental unit) were sacrificed to obtain the carcass yield, prime cuts and organs. Birds were submitted to $8 \mathrm{~h}$ fasting and euthanized by cervical dislocation and subsequent bleeding. After manual plucking, carcasses were gutted, washed, dripped and weighed and quartered. Subsequently, the weight of the prime cuts, viscera and abdominal fat were recorded.

Carcass yield was calculated by comparing the weight of the eviscerated carcass to the live weight of the birds; the yield of thigh, drumstick, breast, wing, abdominal fat, liver and pancreas were determined in relation to the weight of the eviscerated carcass. Abdominal fat was composed of adipose tissue present around the cloaca, gizzard, proventriculus and adjacent abdominal muscles.

To evaluate the intestinal morphology at $\mathrm{d} 42$ of age, two birds (ranging $\pm 5 \%$ of the average weight of the experimental unit) were sacrificed. Duodenum, jejunum, and ileum were collected to assess the villus height and crypt depth using light microscopy. After the semi-serial microtome $(7 \mu \mathrm{m})$, the slides were stained using hematoxylin with eosin technique [11].

The statistical analysis were performed using the System for Statistical Analyses and Genetics (SAEG) [12]. All variables were submitted to analysis of variance and subsequent polynomial regression. Additionally, Dunnett's test was used to compare the dietary inclusion levels of SC (5\%, 10\%, 15\%, and $20 \%$ ) with the control diet ( $0 \%$ SC).

\section{RESULTS AND DISCUSSION}

No interaction was observed between enzyme complex and inclusion levels of SC in relation to performance traits, prime cuts, organ yields and intestinal morphology. Non-ruminant animals are not able to digest non-starch polysaccharides and, therefore, the use of endogenous enzymes can be an alternative to improve nutrient utilization and increase energy available to such animals. However, in our study, no differences were observed between treatments with or without enzyme complex supplementation for performance traits (Table 2).

It is important to consider that enzyme supplementation occurred after $21 \mathrm{~d}$ of age, the stage in which birds already have a well-developed digestive tract with higher digestion capacity 
Table 1. Composition of diets containing levels of sunflower cake for broilers

\begin{tabular}{|c|c|c|c|c|c|c|c|c|c|c|}
\hline \multirow{3}{*}{ Items } & \multicolumn{5}{|c|}{21 to $35 \mathrm{~d}$ of age } & \multicolumn{5}{|c|}{35 to $42 \mathrm{~d}$ of age } \\
\hline & \multicolumn{5}{|c|}{ SC levels (\%) } & \multicolumn{5}{|c|}{ SC levels (\%) } \\
\hline & 0 & 5 & 10 & 15 & 20 & 0 & 5 & 10 & 15 & 20 \\
\hline \multicolumn{11}{|l|}{ Ingredients (\%) } \\
\hline Corn & 59.415 & 55.468 & 51.559 & 47.648 & 41.387 & 62.910 & 58.579 & 53.740 & 48.598 & 44.684 \\
\hline Soybean meal (45\%) & 31.713 & 29.769 & 27.795 & 25.826 & 24.280 & 28.505 & 26.959 & 24.751 & 23.204 & 21.233 \\
\hline Soybean oil & 4.001 & 4.702 & 5.387 & 6.083 & 6.700 & 4.059 & 4.762 & 5.493 & 6.110 & 6.800 \\
\hline Sugar & 1.000 & 1.000 & 1.000 & 1.000 & 3.000 & 1.000 & 1.000 & 2.113 & 3.000 & 3.000 \\
\hline Dicalcium phosphate & 1.294 & 1.317 & 1.334 & 1.350 & 1.364 & 1.077 & 1.101 & 1.118 & 1.135 & 1.149 \\
\hline Limestone & 0.904 & 0.997 & 1.091 & 1.184 & 1.274 & 0.812 & 0.904 & 0.999 & 1.090 & 1.183 \\
\hline Salt & 0.458 & 0.461 & 0.464 & 0.467 & 0.470 & 0.445 & 0.449 & 0.451 & 0.455 & 0.458 \\
\hline DL-Met (99\%) & 0.302 & 0.335 & 0.369 & 0.403 & 0.438 & 0.275 & 0.308 & 0.341 & 0.377 & 0.411 \\
\hline L-Lys HCl (78\%) & 0.260 & 0.290 & 0.320 & 0.350 & 0.372 & 0.267 & 0.287 & 0.321 & 0.343 & 0.374 \\
\hline L-Thr (98\%) & 0.078 & 0.080 & 0.083 & 0.085 & 0.087 & 0.073 & 0.073 & 0.075 & 0.077 & 0.080 \\
\hline L-Val (99\%) & 0.062 & 0.062 & 0.062 & 0.063 & 0.062 & 0.059 & 0.056 & 0.056 & 0.056 & 0.056 \\
\hline L-Trp (99\%) & 0.000 & 0.004 & 0.018 & 0.020 & 0.045 & 0.000 & 0.006 & 0.021 & 0.034 & 0.048 \\
\hline L-lle (99\%) & 0.018 & 0.020 & 0.023 & 0.026 & 0.026 & 0.023 & 0.021 & 0.026 & 0.026 & 0.029 \\
\hline Vitamin premix ${ }^{1)}$ & 0.100 & 0.100 & 0.100 & 0.100 & 0.100 & 0.100 & 0.100 & 0.100 & 0.100 & 0.100 \\
\hline Choline (60\%) & 0.060 & 0.060 & 0.060 & 0.060 & 0.060 & 0.060 & 0.060 & 0.060 & 0.060 & 0.060 \\
\hline Anticoccidial| ${ }^{2)}$ & 0.060 & 0.060 & 0.060 & 0.060 & 0.060 & 0.060 & 0.060 & 0.060 & 0.060 & 0.060 \\
\hline Mineral premix ${ }^{3)}$ & 0.050 & 0.050 & 0.050 & 0.050 & 0.050 & 0.050 & 0.050 & 0.050 & 0.050 & 0.050 \\
\hline Antioxidant ${ }^{4)}$ & 0.020 & 0.020 & 0.020 & 0.020 & 0.020 & 0.020 & 0.020 & 0.020 & 0.020 & 0.020 \\
\hline Growth promoter ${ }^{5)}$ & 0.005 & 0.005 & 0.005 & 0.005 & 0.005 & 0.005 & 0.005 & 0.005 & 0.005 & 0.005 \\
\hline Inert $^{6)}$ & 0.200 & 0.200 & 0.200 & 0.200 & 0.200 & 0.200 & 0.200 & 0.200 & 0.200 & 0.200 \\
\hline \multicolumn{11}{|l|}{ Calculated composition } \\
\hline Metabolizable energy (kcal/kg) & 3,150 & 3,150 & 3,150 & 3,150 & 3,150 & 3,200 & 3,200 & 3,200 & 3,200 & 3,200 \\
\hline Crude protein (\%) & 19.544 & 19.544 & 19.544 & 19.544 & 19.544 & 18.405 & 18.405 & 18.405 & 18.405 & 18.405 \\
\hline $\mathrm{Ca}(\%)$ & 0.758 & 0.758 & 0.758 & 0.758 & 0.758 & 0.663 & 0.663 & 0.663 & 0.663 & 0.663 \\
\hline Available phosphorus (\%) & 0.354 & 0.354 & 0.354 & 0.354 & 0.354 & 0.309 & 0.309 & 0.309 & 0.309 & 0.309 \\
\hline Digestible Lys (\%) & 1.131 & 1.131 & 1.131 & 1.131 & 1.131 & 1.060 & 1.060 & 1.060 & 1.060 & 1.060 \\
\hline Digestible Met (\%) & 0.558 & 0.600 & 0.641 & 0.683 & 0.725 & 0.520 & 0.561 & 0.602 & 0.645 & 0.686 \\
\hline Digestible Met+Cist (\%) & 0.826 & 0.826 & 0.826 & 0.826 & 0.826 & 0.774 & 0.774 & 0.774 & 0.774 & 0.774 \\
\hline Digestible Thr (\%) & 0.735 & 0.735 & 0.735 & 0.735 & 0.735 & 0.689 & 0.689 & 0.689 & 0.689 & 0.689 \\
\hline Digestible Val (\%) & 0.882 & 0.882 & 0.882 & 0.882 & 0.882 & 0.827 & 0.827 & 0.827 & 0.827 & 0.827 \\
\hline Digestible lle (\%) & 0.769 & 0.769 & 0.769 & 0.769 & 0.769 & 0.721 & 0.721 & 0.721 & 0.721 & 0.721 \\
\hline Digestible Trp (\%) & 0.213 & 0.204 & 0.204 & 0.204 & 0.204 & 0.196 & 0.191 & 0.191 & 0.191 & 0.191 \\
\hline Digestible Arg (\%) & 1.207 & 1.227 & 1.246 & 1.265 & 1.290 & 1.145 & 1.145 & 1.161 & 1.186 & 1.205 \\
\hline $\mathrm{Na}(\%)$ & 0.200 & 0.200 & 0.200 & 0.200 & 0.200 & 0.195 & 0.195 & 0.195 & 0.195 & 0.195 \\
\hline $\mathrm{K}(\%)$ & 0.760 & 0.705 & 0.658 & 0.611 & 0.576 & 0.711 & 0.669 & 0.622 & 0.565 & 0.518 \\
\hline
\end{tabular}

SC, sunflower cake.

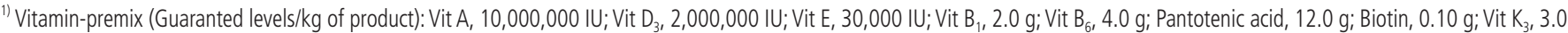
g; Folic acid, $1.0 \mathrm{~g}$; Nicotinic acid, $50.0 \mathrm{~g}$; Vit B12, 15,000 mcg; Se, $0.25 \mathrm{~g}$; vehicle q.s.p., 1,000 g.

2) Salinomycin $12 \%$.

${ }^{3)}$ Mineral-premix (Guaranted levels/kg of product): Mg, $16.0 \mathrm{~g}$; Fe, $100.0 \mathrm{~g}$; Zn, 100.0g; Cu, $2.0 \mathrm{~g}$; Co, $2.0 \mathrm{~g}$; I, 2.0 g; vehicle q.s.p., 1,000 g.

${ }^{4)} \mathrm{BHT}$, butyl hydroxy toluene. ${ }^{5)}$ Virginiamycin. ${ }^{6}$ Sand.

and absorption of nutrients. Tavernari et al [13] observed higher WG for broiler chickens aged 1 to $21 \mathrm{~d}$ that did not receive an enzymatic complex in the diet, although they did not consider energy recovery of enzymes in the diet formulations.

Excluding the birds fed the control diet ( $0 \% \mathrm{SC}$ ), regression analysis showed that FI, WG, final weight, and F:G linearly worsened ( $\mathrm{p}=0.23,0.12,0.12$, and 0.05 , respectively) as dietary SC increased, which can be confirmed by the adjustment of regression equations. Studying the inclusion of SC in the diets of broiler chickens from 20 to $42 \mathrm{~d}$ of age, Oliveira et al [4] observed a worse F:G ratio and a quadratic effect on FI, which reduced from $9.6 \%$ of SC, indicating that its use should be limited in broiler chicken diets.

The decrease in FI with rising inclusion of SC, as observed in our study, may be associated with reduction in the food passage rate; because when non-starch polysaccharides are undigested, the viscosity of the chyme increases due to its high affinity for water and reduces the food passage rate. It impairs enzyme action and then the digestibility and utilization of other nutrients, which may be related to reduced WG and increased F:G ratio 
Table 2. Growth performance of broilers fed sunflower cake and enzymatic complex from 21 to $42 \mathrm{~d}$ of age

\begin{tabular}{|c|c|c|c|c|}
\hline Items & Feed intake (g) & Weight gain (g) & Final weight (g) & Feed:gain ratio $(\mathrm{g} / \mathrm{g})$ \\
\hline \multicolumn{5}{|c|}{ Inclusion levels of SC (\%) } \\
\hline 0 & $2,934.50 \pm 16.86$ & $1,682.37 \pm 19.14$ & $2,421.49 \pm 19.35$ & $1.746 \pm 0.021$ \\
\hline 5 & $2,926.60 \pm 11.92$ & $1,633.92 \pm 30.79$ & $2,370.33 \pm 33.03$ & $1.796 \pm 0.031$ \\
\hline 10 & $2,921.28 \pm 24.53$ & $1,616.61 \pm 18.13$ & $2,356.08 \pm 18.52$ & $1.803 \pm 0.020$ \\
\hline 15 & $2,912.46 \pm 13.92$ & $1,589.51 \pm 20.51^{*}$ & $2,330.39 \pm 21.09^{*}$ & $1.822 \pm 0.017^{*}$ \\
\hline 20 & $2,873.53 \pm 17.38$ & $1,542.72 \pm 19.58^{*}$ & $2,284.42 \pm 18.99^{*}$ & $1.864 \pm 0.020^{*}$ \\
\hline SEM & 8.23 & 10.42 & 10.78 & 0.010 \\
\hline Levels $\times \mathrm{EC}$ & 0.93 & 0.97 & 0.97 & 0.96 \\
\hline EC & 0.82 & 0.60 & 0.66 & 0.29 \\
\hline Levels & 0.23 & 0.12 & 0.12 & 0.05 \\
\hline Linear & 0.05 & $<0.01$ & 0.04 & 0.01 \\
\hline
\end{tabular}

SC, sunflower cake; EC, enzymatic complex; SEM, standard error of the mean.

* Dunnett's test, considering significant when $p<0.05$.

observed in our study.

Considering the Dunnett's test, we observed no difference in FI between birds fed the experimental diets and those fed as controls. This is in line with scerbo et al [14], whose found no difference in FI for broiler chickens fed diets with SC up to $12 \%$ inclusion. Tavernari et al [15] studied sunflower meal to broilers from 22 to $42 \mathrm{~d}$ of age and did not find differences in FI. When birds' diets contained up to $15 \%$ sunflower meal, Furlan et al [16] demonstrated improved the performance traits of broiler chickens; however, the authors reported that lysine and energy should be supplemented to meet the requirements.

Birds fed SC levels of 15\% and 20\% showed worse WG, FW, and F:G values compared to birds fed the control diet. From this we can infer that including up to $10 \%$ SC in broiler chicken diets results in similar performance compared to control diet. Oliveira et al [4] reported that using $12.3 \%$ of SC did not negatively affect WG of broilers. Scerbo et al [14] also demonstrated that a $12 \%$ SC inclusion beyond $25 \mathrm{~d}$ of age did not impair WG of broilers.

Intestinal morphometry data showed that the enzymatic complex improved $(\mathrm{p}<0.05)$ the crypt depth and, consequently, the villus: crypt ratio in the jejunum (Table 3). It is desirable that intestinal villi are high and crypt is shallow because the higher the ratio of villus height: crypt depth, the better will be the absorption of nutrients and the less energy will be needed for cell turnover [17].

According to Maiorka et al [18], the development of intestinal mucosa results primarily from two associated cytological events:

Table 3. Histomorphometric parameters of small intestine of broilers fed sunflower cake and enzymatic complex from 21 to $42 \mathrm{~d}$ of age

\begin{tabular}{|c|c|c|c|c|c|c|c|c|c|}
\hline & \multicolumn{3}{|c|}{ Villus height $(\mu \mathrm{m})$} & \multicolumn{3}{|c|}{ Crypt depth $(\mu \mathrm{m})$} & \multicolumn{3}{|c|}{ Villus:crypt ratio } \\
\hline & Duodenum ${ }^{1)}$ & Jejunum ${ }^{2)}$ & Ileum $^{3)}$ & Duodenum ${ }^{4)}$ & Jejunum ${ }^{5)}$ & Ileum $^{6)}$ & Duodenum ${ }^{7)}$ & Jejunum ${ }^{8)}$ & Ileum $^{9)}$ \\
\hline \multicolumn{10}{|c|}{ SC inclusion (\%) } \\
\hline 0 & $1,423.07 \pm 22.00$ & $1,025.93 \pm 38.63$ & $843.62 \pm 21.65$ & $147.29 \pm 2.08$ & $151.66 \pm 2.99$ & $135.32 \pm 1.70$ & $9.67 \pm 0.17$ & $6.81 \pm 0.33$ & $6.25 \pm 0.19$ \\
\hline 5 & $1,394.56 \pm 26.03$ & $955.42 \pm 23.85$ & $826.58 \pm 18.79$ & $147.30 \pm 2.46$ & $153.66 \pm 2.73$ & $138.78 \pm 5.82$ & $9.52 \pm 0.33$ & $6.24 \pm 0.20$ & $6.08 \pm 0.34$ \\
\hline 10 & $1,338.84 \pm 25.45$ & $932.49 \pm 17.28^{*}$ & $773.54 \pm 18.94^{*}$ & $151.75 \pm 3.75$ & $163.71 \pm 2.29 *$ & $145.85 \pm 4.66$ & $8.88 \pm 0.29$ & $5.71 \pm 0.12^{*}$ & $5.36 \pm 0.21 \times$ \\
\hline 15 & $1,320.32 \pm 40.83^{*}$ & $893.81 \pm 14.98^{*}$ & $730.49 \pm 17.40^{*}$ & $151.37 \pm 4.31$ & $167.62 \pm 3.47^{*}$ & $147.25 \pm 1.84$ & $8.85 \pm 0.48$ & $5.36 \pm 0.15^{*}$ & $4.97 \pm 0.16^{*}$ \\
\hline 20 & $1,285.30 \pm 22.11$ * & $885.74 \pm 20.37^{\star}$ & $701.89 \pm 19.25^{*}$ & $158.93 \pm 2.66$ & $167.36 \pm 2.53^{*}$ & $153.85 \pm 1.92^{*}$ & $8.11 \pm 0.20^{\star}$ & $5.31 \pm 0.18^{*}$ & $4.57 \pm 0.13^{*}$ \\
\hline With EC & $1,349.82 \pm 24.33$ & $956.75 \pm 20.15$ & $790.04 \pm 16.62$ & $149.74 \pm 2.18$ & $156.66 \pm 2.39^{\mathrm{a}}$ & $143.24 \pm 2.97$ & $9.09 \pm 0.25$ & $6.17 \pm 0.20^{\mathrm{a}}$ & $5.61 \pm 0.21$ \\
\hline Without EC & $1,355.02 \pm 15.55$ & $920.62 \pm 15.86$ & $760.41 \pm 15.43$ & $152.92 \pm 2.12$ & $164.95 \pm 1.75^{b}$ & $145.18 \pm 2.24$ & $8.92 \pm 0.20$ & $5.60 \pm 0.12^{b}$ & $5.28 \pm 0.15$ \\
\hline SEM & 13.27 & 11.54 & 9.08 & 1.49 & 1.33 & 1.70 & 0.15 & 0.10 & 0.10 \\
\hline Levels $\times \mathrm{EC}$ & 0.72 & 0.36 & 0.14 & 0.47 & 0.56 & 0.56 & 0.67 & 0.37 & 0.30 \\
\hline EC & 0.79 & 0.14 & 0.13 & 0.49 & 0.67 & 0.69 & 0.78 & $<0.01$ & 0.16 \\
\hline Levels & 0.14 & 0.066 & $<0.01$ & 0.17 & 0.13 & 0.13 & 0.09 & $<0.01$ & $<0.01$ \\
\hline Linear & 0.02 & 0.01 & $<0.01$ & 0.04 & $<0.01$ & 0.02 & 0.01 & $<0.01$ & $<0.01$ \\
\hline Quadratic & 0.74 & 0.72 & 0.54 & 0.66 & 0.09 & 0.96 & 0.89 & 0.16 & 0.51 \\
\hline
\end{tabular}

SC, sunflower cake; EC, enzymatic complex; SEM, standard error of the mean.

1) $1421.33-6.92563 \times S C, R^{2}=0.96 ; i^{21} 978.799-4.9544 \times S C, R^{2}=0.95 ;{ }^{3)} 862.397-8.34181 \times S C, R^{2}=0.98 ;{ }^{4)} 143.714+0.690114 \times S C, R^{2}=0.85 ;{ }^{51} 151.835+0.900153 \times S C, R^{2}$

$=0.79 ;{ }^{6}{ }^{6} 134.784+0.931747 \times S C, R^{2}=0.95 ;{ }^{7)} 9.90523-0.0852646 \times S C, R^{2}=0.91 i^{8)} 6.43739-0.0626453 \times S C, R^{2}=0.89 ;{ }^{9}{ }^{9} 6.48112-0.0988052 \times S C, R^{2}=0.97$.

* Dunnett's test, considering significant when $p<0.05$.

a,b Different letters in the same column are different by $F$ test $(p<0.05)$. 
cellular renewal (mitosis) and cell loss (extrusion). The high amount of cell renewal in intestinal mucosa is due to hyperplasia, which results from high mitotic activity.

Enzyme activity probably reduces intestinal viscosity; otherwise, it could impair the mucous layer and compromise the integrity of intestinal epithelial cells. Moreover, according to Viveros et al [19], enzymes can improve the microflora by increasing the growth of beneficial bacteria that maintain intestinal health by degrading the fiber in the diet.

Considering the regression analysis, all variables of intestinal morphology worsened as SC levels increased; the villus height and villus:crypt ratio in the duodenum, jejunum and ileum linearly reduced $(\mathrm{p}=0.14,0.066$, and $<0.01 ; 0.09,<0.01$, and $<0.01$, respectively), according to increasing levels of SC, while crypt depth increased linearly ( $\mathrm{p}=0.17,0.13,0.13$, respectively). This suggests that non-starch polysaccharides have a negative effect on nutrient utilization in the intestinal tract, which justifies the poor broiler performance, according to the inclusion levels of SC in the birds' diets. Evaluating the inclusion of fiber for broiler chickens, Morita [20] observed reductions in villus height in three segments of small intestine as fiber increased in the diets.

Similarly, Moghaddam et al [21] observed a decrease in the villus height and increase in crypt depth in the duodenum and jejunum of cocks as the levels of sunflower meal increased and reported that these effects can reduce nutrients absorption, increase secretion in the intestinal tract and reduce performance and resistance to diseases.

The increase in crypt depth indicates high cell turnover and tissue renewal [22], which in turn increases intestinal maintenance requirements and reduces the efficiency of broiler production [21].

Working with sunflower seeds with high fat content in broilers' diets, Arija et al [23] observed the presence of many dark granules inside the enterocytes vacuoles. These could be triglyceride-rich lipoproteins (portomicrons) that developed due to the presence of toxic compounds in sunflower seed, such as chlorogenic acid (7 g/ $\mathrm{kg})$, or due to higher oil concentration in the diet $(9 \%)$ or due to the absence of apoproteins necessary for the synthesis and transport of lipoproteins for the intestinal blood vessels, which cause the vacuolar degeneration of enterocytes as well as hyperplasia of goblet cells.

Dunnett's test shows that for birds fed 15\% and 20\% dietary levels of SC, the villus height in the duodenum was lower than that of birds fed the control diet $(\mathrm{p}<0.05)$. Considering the villus height of jejunum and ileum, the crypt depth of jejunum and villus:crypt ratio of jejunum and ileum, the birds fed 10\%, 15\%, and $20 \%$ of SC showed worse results $(\mathrm{p}<0.05)$ than the control diet, especially for the highest level of SC. Crypt depth of ileum and the villus: crypt ratio of duodenum showed the worst values at $20 \%$ of SC.

Carcass, thigh and liver yield were higher $(\mathrm{p}<0.05)$ for birds receiving the enzymatic complex, while chest yield, drumstick, wings and pancreas were higher for birds receiving no enzymatic complex (Table 4).

The utilization of enzymatic complex (xylanase, amylase, and protease) in diets for broiler chickens reduced the carcass yield [24]. Tavernari et al [13] using diets supplemented with enzymatic complex, did not find an effect of enzymes on the yield of broiler chicken carcass, abdominal fat, thigh and chest.

The results observed for liver and pancreas yield are consistent, since the utilization of exogenous enzymes can reduce pancreas activity by a lesser need for enzyme production, which reduces its relative weight [25]. On the other hand, the increasing in liver yield can be explained by its greater activity due to higher nutritional support with enzyme utilization. Santos et al [24]

Table 4. Carcass yield, prime cuts, organs and abdominal fat yield (\%) of broilers fed sunflower cake and enzymatic complex, from 21 to $42 \mathrm{~d}$ of age

\begin{tabular}{|c|c|c|c|c|c|c|c|c|}
\hline Items & Carcass $^{1)}$ & Chest & Drumstick & Thigh & Wings & Abdominal fat & Liver & Pancreas \\
\hline \multicolumn{9}{|c|}{ SC inclusion (\%) } \\
\hline 0 & $71.78 \pm 0.29$ & $36.81 \pm 0.23$ & $15.80 \pm 0.23$ & $14.01 \pm 0.20$ & $11.03 \pm 0.16$ & $2.04 \pm 0.14$ & $2.89 \pm 0.09$ & $0.25 \pm 0.01$ \\
\hline 5 & $71.45 \pm 0.31$ & $36.78 \pm 0.22$ & $15.81 \pm 0.15$ & $14.25 \pm 0.08$ & $11.19 \pm 0.12$ & $2.06 \pm 0.13$ & $2.69 \pm 0.15$ & $0.28 \pm 0.01$ \\
\hline 10 & $70.98 \pm 0.38$ & $36.75 \pm 0.15$ & $15.92 \pm 0.21$ & $13.81 \pm 0.08$ & $11.17 \pm 0.14$ & $2.16 \pm 0.15$ & $2.71 \pm 0.10$ & $0.29 \pm 0.01$ \\
\hline 15 & $70.56 \pm 0.40$ & $36.31 \pm 0.07$ & $16.10 \pm 0.28$ & $14.33 \pm 0.10$ & $11.21 \pm 0.17$ & $1.89 \pm 0.07$ & $2.75 \pm 0.09$ & $0.30 \pm 0.02$ \\
\hline 20 & $70.07 \pm 0.43^{*}$ & $36.08 \pm 0.10$ & $15.98 \pm 0.19$ & $14.05 \pm 0.08$ & $10.99 \pm 0.13$ & $1.85 \pm 0.15$ & $2.75 \pm 0.09$ & $0.28 \pm .02$ \\
\hline With EC & $71.36 \pm 0.20^{a}$ & $36.27 \pm 0.04^{\mathrm{a}}$ & $15.72 \pm 0.15^{\mathrm{a}}$ & $14.12 \pm 0.10^{a}$ & $10.79 \pm 0.06^{a}$ & $1.97 \pm 0.09$ & $2.85 \pm 0.07^{a}$ & $0.26 \pm 0.01^{\mathrm{a}}$ \\
\hline Without EC & $70.59 \pm 0.29^{b}$ & $36.82 \pm 0.15^{b}$ & $16.13 \pm 0.12^{b}$ & $14.06 \pm 0.07^{b}$ & $11.44 \pm 0.08^{b}$ & $2.02 \pm 0.08$ & $2.66 \pm 0.06^{b}$ & $0.29 \pm 0.01^{b}$ \\
\hline SEM & 0.17 & 0.09 & 0.10 & 0.06 & 0.07 & 0.06 & 0.05 & 0.006 \\
\hline Levels $\times \mathrm{EC}$ & 0.28 & 0.42 & 0.098 & 0.24 & 0.20 & 0.46 & 0.38 & 0.16 \\
\hline $\mathrm{EC}$ & $<0.01$ & $<0.01$ & 0.14 & 0.01 & $<0.01$ & 0.17 & 0.11 & 0.01 \\
\hline Levels & 0.067 & 0.38 & 0.57 & 0.48 & 0.35 & 0.36 & 0.78 & 0.57 \\
\hline Linear & 0.01 & 0.17 & 0.51 & 0.70 & 0.40 & 0.14 & 0.66 & 0.96 \\
\hline Quadratic & 0.97 & 0.83 & 0.59 & 0.71 & 0.51 & 0.62 & 0.93 & 0.44 \\
\hline
\end{tabular}

SC, sunflower cake; EC, enzymatic complex; SEM, standard error of the mean.

1) $71.9093-0.0912511 \times S C_{1} R^{2}=1.00$.

* Dunnett's test, considering significant when $p<0.05$

${ }^{a, b}$ Different letters in the same column are different by $F$ test $(p<0.05)$. 
observed that the addition of enzymatic complex in the broilers' diets did not affect the relative weight of liver and pancreas.

Carcass yield reduced linearly $(\mathrm{p}<0.067)$ as SC levels increased; considering the Dunnett's test, the birds fed $20 \%$ of SC showed lower carcass yield than birds on the control diet. This indicates that the utilization of up to $15 \%$ of SC did not impair the carcass yield; however, it linearly reduced due to a negative effect of fiber on nutrient utilization. Additionally, these effects may be related to the linear reduction in the birds' WG, according to the increasing levels of SC. Tavernari et al [15] and Oliveira et al [26], using sunflower meal at levels up to $20 \%$ and $30 \%$, observed no effect on carcass yield.

\section{CONCLUSION}

Considering the performance data, $\mathrm{SC}$ can be included in broiler chicken diets up to $10 \%$ when feeding birds from 21 to $42 \mathrm{~d}$ of age. Nutrients utilization may be impaired when SC is more than $5 \%$ of the diet.

\section{CONFLICT OF INTEREST}

We certify that there is no conflict of interest with any financial organization regarding the material discussed in the manuscript.

\section{ACKNOWLEDGMENTS}

The work was supported by the Araucaria Foundation of Research Support of Paraná State.

\section{REFERENCES}

1.Pasquetti TJ, Furlan AC, Ton APS, et al. Semi-purified glycerin in the meat quails feeding. Semina:Ciênc Agrár 2014;35:3377-92.

2.Gomes JDF, Fukushima RS, Putrino SM, Grossklaus C, Lima GJMM. Effects of increasing neutral detergent fiber in swine diets on the morphology of digestive and non-digestive organs. Braz J Vet Res Anim Sci 2006;3:202-9.

3.Pedreiro GEG, Silva CA, Bridi AM, et al. Sunflower cake to sows feeding on gestation and lactation phases. Semina: Ciênc Agrár 2009;30:497-503.

4. Oliveira DD, Pinheiro JW, Fonseca NAN, Oba A. Performance of broiler chickens fed with sunflower cake. Semina: Ciênc Agrár 2012; 33:1979-90.

5.Geron LJV. Utilization of agroindustrial waste in livestock feed. Pubvet 2007;1:110-25.

6. Oliveira MDS, Mota DA, Barbosa JC, Stein M, Borgonovi F. Chemical bromatologic composition and in vitro ruminal digestibility of concentrates containing different levels of sunflower quacker. Ciênc Anim Bras 2007;8:629-38.

7.Janssen WMMA, Carré B. Influence of fiber on digestibility of poultry feed. In: Cole DJA, Haresign W, editors. Recent developments in poultry nutrition. London: Butterworths; 1989. p. 78-93.

8.Berwanger E, Nunes RV, Pozza PC, et al. Nutritional and energy values of sunflower cake for broilers. Semina: Ciênc Agrár 2014; 35:3429-38.

9.Rostagno HS, Albino LFT, Donzele JL, et al. Brazilian tables for poultry and swine: food composition and nutrient requirements. 3rd ed. Viçosa, MG, Brazil: Universidade Federal de Viçosa, 2011.

10. Sakomura NK, Rostagno HS. Research Methods in Monogastric Nutrition. 1st ed. Jaboticabal, SP: Funep; 2007.

11. Lillie RD. Histopathologic Technic and Practical Histochemistry. 2nd ed. New York: Blakiston; 1954.

12. Federal University of Viçosa, System for Statistical Analyses and Genetics - SAEG. Version 9.0. Viçosa, MG, Brazil: Federal University of Viçosa; 2005.

13. Tavernari FC, Albino LFT, Morata RL, et al. Inclusion of sunflower meal with or without enzyme supplementation in broiler diets. Rev Bras Cienc Avic 2008;10:233-8.

14. Scerbo DC, Koritiaki NA, Camolezzi GB, Pinheiro JW, Fonseca NAN. Broiler performance fed with sunflower cake. In: Proceedings of 46th Annual Meeting of the Brazilian Society of Animal Science 2009; 2009 Jul 14-17: Maringá, PR, Brazil: Brazilian Society of Animal Science; 2009. pp. 1.

15. Tavernari FC, Dutra Júnior WM, Albino LFT, et al. Effect of different levels of sunflower meal in diets on the performance of broiler chickens. R Bras Zootec 2009;38:1745-50.

16. Furlan AC, Mantovani C, Murakami AE, et al. Use of sunflower meal in broiler chicks feeding. Rev Bras Zootec 2000;30:158-64.

17. Nabuus MJA. Microbiological, structural and functional changes of the small intestine of pigs at weaning. Pigs News Inf 1995;16:937.

18. Maiorka A, Santin E, Dahlke F, et al. Posthatching water and feed deprivation affect the gastrointestinal tract and intestinal mucosa development of broiler chicks. J Appl Poult Res 2003;12:483-92.

19. Viveros A, Brenes A, Pizarro M, Castaño M. Effect of enzyme supplementation of a diet based on barley and autoclave treatment on apparent digestibility, growth performance and gut morphology of broilers. Anim Feed Sci Technol 1994;48:237-51.

20. Morita VS. Effect of citrus pectin on health and development of small intestine of broiler. [PhD thesis]. Jaboticabal, SP: Faculty of Agricultural and Veterinary Sciences, São Paulo State University; 2011.

21. Moghaddam HN, Salari S, Arshami J, Golian A, Maleki M. Evaluation of the nutritional value of sunflower meal and its effect on performance, digestive enzyme activity, organ weight, and histological alterations of the intestinal villi of broiler chickens. J Appl Poult Res 2012;21:293-304.

22. Yason CV, Summers BA, Schat KA. Pathogenesis of rotavirus infection in various age groups of chickens and turkeys: pathology. Am J Vet Res 1987;48:927-38.

23. Arija I, Viveros A, Brenes A, et al. Histological alterations in the intestinal epithelium caused by the inclusion of full-fat sunflower kernels in broiler chicken diets. Poult Sci 2000;79:1332-4. 
24. Santos MSV, Espíndola GB, Fuentes MFF, Freitas ER, Carvalho LE. Effects of feeding sorghum-soya of enzymatic supplementation on broiler chickens based diet. R Bras Zootec 2006;35:811-7.

25. Han Z. Effect of enzyme supplementation of diets on the physiological function and performance of poultry. In: Marquardt RR, Han Z, editors. Enzymes in Poultry and Swine Nutrition. Ottawa, ON: International Development Research Centre; 1997. p. 29-44.

26. Oliveira MC, Martins FF, Almeida CV, Moura CD. Effect of inclusion levels of sunflower meal in rations on the performance and carcass yield of broilers. Rev Port Zootec 2003;10:107-16. 